\title{
EDITORIAL
}

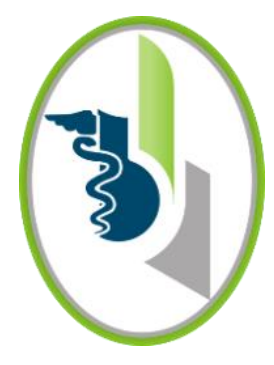

ACCESO ABIERTO

Copyright: (C) 2020. Forero, E. Este es un artículo de acceso abierto, distribuido bajo los términos de la licencia https://creativecommons.org/licenses/by-nc-

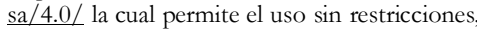
distribución y reproducción en cualquier medio, siempre y cuando el original, el autor y la fuente sean acreditados.

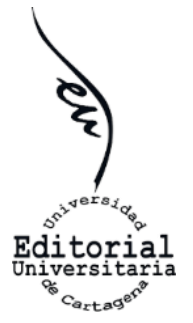

\section{De distopias y academias}

Ni el más distópico de los cineastas pudo imaginar la conducta tomada por un sector de la sociedad ante la pandemia inducida por el SARS-COV-2. Jefes de estado, profesionales de la salud y personajes de amplio reconocimiento han decidido recomendar "efectivos" tratamientos contra el COVID-19 sin disponer de un respaldo científico adecuado y en algunos casos sin el más mínimo asidero teórico.

Aunque desde siempre la sabiduría popular ha recomendado toda clase de medidas contra cada epidemia que se presente (1), esta pandemia vino con un respaldo mayor.

El ejemplo más relevante, es la recomendación hecha por la Casa Blanca para el consumo de la Cloroquina y la Hidroxicloroquina como tratamiento eficaz contra la infección. Sus promotores se apoyan en un mecanismo de acción seductor que bloquea la entrada del virus a las células por inhibir la glicosilación de los receptores del huésped, el procesamiento proteolítico y la acidificación endosomal. Estos agentes también poseen convenientes efectos inmunomoduladores a través de la atenuación de la producción de citoquinas, la inhibición de la autofagia y la actividad lisosómica en las células huésped. Desafortunadamente estas bases teóricas no son respaldadas por evidencia de alta calidad. Los estudios publicados a la fecha muestran tales limitaciones en los diseños (2), que hacen difícil aceptar sus resultados, por muy convenientes que parezcan los fundamentos teóricos.

Si la Casa Blanca sorprende con sus posturas, algunos médicos no se quedan atrás. Las redes están inundadas de colegas recomendando tratamientos sin ningún fundamento. Tomar ocho tabletas de aspirina diarias para mejorar la circulación de estos pacientes, hacer gárgaras con agua caliente y sal, o consumir el famosísimo dióxido de cloro, son sólo algunos ejemplos de las sustancias avaladas por profesionales de la salud, con intereses imposibles de descifrar.

El problema no es que las recomendaciones sean falsas o que el promotor quede como un necio cuando se demuestre la imprecisión de sus aseveraciones. El verdadero problema es que, mientras se demuestra la falsedad de dichas recomendaciones, muchos enfermos no reciben el verdadero cuidado o sufren los efectos adversos de tratamientos innecesarios.

Es inevitable preguntarse cómo un jefe de estado promueve conductas que ponen en riesgo a sus conciudadanos, o porqué algunos médicos argumentan que sus prescripciones empíricas o sus tratamientos no ortodoxos pueden ayudar a mejorar a los pacientes. Probablemente el dinero no sea el factor motivacional para la mayoría de estos promotores, pero tal vez sí lo es la premura por encontrarle salida a una situación sin precedentes, que tiene entre la espada y la pared a la población mundial. 
¿Vale la pena el riesgo de ser desmentido públicamente a cambio de la fama efímera obtenida en las redes sociales? resulta que sí vale, porque la verdadera ciencia, la que tiene el conocimiento, está tan ocupada tratando de resolver los problemas reales que no tiene tiempo de salir a desmentir tanta información irresponsable que se publica. Los minutos de fama por las informaciones falsas son abrumadoramente mayores.

Las cifras de replicaciones que se producen tras la publicación de una noticia falsa superan con creces a las verdaderas noticias, la fama no es efímera. Que la aspirina sirve para el tratamiento del COVID-19, que las mascarillas producen enfermedad pulmonar, que los médicos están intubando pacientes para llenar las unidades de cuidado intensivo, que los cadáveres deben ser cremados, que las pruebas no sé qué, en fin, todas las informaciones publicadas en las redes sociales son consideradas verdaderas por absurdas que parezcan. La pandemia no solo trajo la cuarentena y la muerte, también llegó el 'infocalipsis'.

Ante este caos informativo y antes de que la ficción supere a la realidad, la academia debe salir al paso de médicos, presidentes y todo aquel que con informaciones falsas pretenda inducir a la población a consumir medicamentos o sustancias sin fundamento científico. La academia para cumplir con este fin, dispone de dos valiosos recursos. El primero es la información actualizada, las grandes editoriales médicas facilitaron el acceso libre a la literatura científica sobre el COVID-19. Segundo, todos los centros académicos se esmeran por exponer en sus redes sociales toda la información que se deriva de las investigaciones que aparecen sobre el tema. La academia apertrechada con la información adecuada y con medios de difusión veraces puede librar en mejores condiciones esta lucha desigual contra las falsas noticias y sus poderosos promotores.

\author{
Elías Gonzalo Forero Illera \\ MD, Internista Reumatólogo \\ Profesor \\ Universidad del Norte \\ Barranquilla, Colombia
}

\title{
REFERENCIAS
}

1. http://www.cervantesvirtual.com/obra-visor/remedios-caseros-para-lasenfermedades-humanas/html/

2. Sanders JM, Monogue ML, Jodlowski TZ, Cutrell JB. Pharmacologic Treatments for Coronavirus Disease 2019 (COVID-19): A Review. JAMA. 2020;323(18):1824-1836. doi:10.1001/jama.2020.6019 